\title{
PERLINDUNGAN HUKUM LELANG EKSEKUSI HAK TANGGUNGAN
}

\author{
Asuan \\ Fakultas Hukum Universitas Palembang \\ E-mail: asuan.okay@gmail.com
}

\begin{abstract}
Parate Executie or direct execution, namely the execution of mortgage rights which is carried out by selling the object of the mortgage right by the holder of the first mortgage on his own power through a public auction and taking the payment of the debt from the sale proceeds. Protection of mortgage auction has actually been carried out in a preventive manner by the State Wealth and Auction Service Office (KPKNL) because prior to the auction, KPKNL notifies the auction participants regarding the documents, conditions and conditions of the object to be auctioned in truth and as it is as well as the consequences and risks that may arise from the auction object. Regarding repressive protection, namely efforts to obtain legal protection through judicial bodies and obstacles to implementation, there is no agreement on the price of the object being auctioned.
\end{abstract}

Key words: Execution Auction; Mortgage Right

\begin{abstract}
Abstrak
Parate Executie atau eksekusi langsung yaitu eksekusi hak tanggungan yang dilakukan dengan cara menjual objek hak tanggungan oleh pemegang hak tanggungan pertama atas kekuasaan sendiri melalui pelelangan umum serta mengambil pelunasan piutangnya dari hasil penjualan tersebut. Perlindungan lelang hak tanggungan sebenarnya telah dilakukan secara preventif oleh Kantor Pelayanan Kekayaan Negara dan Lelang (KPKNL) karena sebelum dilakukannya pelelangan, KPKNL memberitahukan kepada peserta lelang terkait dengan dokumendokumen, keadaan dan kondisi objek yang akan dilelang dengan sebenar-benarnya dan apa adanya, serta konsekuensi dan resiko yang dapat timbul dari objek lelang. Terkait perlindungan secara represif yaitu upaya untuk mendapatkan perlindungan hukum melalui badan peradilan dan hambatan dalam pelaksakanaan tidak terdapat kesepakatan masalah harga objek yang dilelang tertebut
\end{abstract}

Kata Kunci: Lelang Eksekusi; Hak Tanggungan

\section{PENDAHULUAN}

Lembaga keuangan bank merupakan lembaga yang bersifat sebagai perantara bagi mereka yang membutuhkan uang dengan mereka yang memiliki uang berlebih. Lembaga keuangan bank tidak terlepas dari kehidupan ekonomi suatu negara dan berperan penting dalam memajukan perekonomian serta pemerataan pertumbuhan ekonomi masyarakat.
Ketentuan-ketentuan mengenai lembaga keuangan bank diatur dalam Undang-Undang Nomor 7 Tahun 1992 j.o. Undang-Undang Nomor 10 Tahun 1998 tentang Perbankan (selanjutnya disebut dengan UU Perbankan) dan Undang-Undang Nomor 23 Tahun 1999 j.o. 3 Tahun 2004 tentang Bank Indonesia. Fungsi bank dapat ditemui dalam pasal 1 angka 2 UU Perbankan, yang 
Asuan, Perlindungan Hukum Lelang Eksekusi Hak Tanggungan, Halaman 272-289

menyatakan bahwa bank adalah badan usaha yang menghimpun dana dari masyarakat dalam bentuk simpanan dan menyalurkannya kepada masyarakat dalam bentuk kredit dan atau bentuk-bentuk lainnya dalam rangka meningkatkan taraf hidup rakyat banyak. Berdasarkan ketentuan tersebut, maka dapat diketahui fungsi utama bank yaitu sebagai penghimpun dan penyalur dana masyarakat. $^{1}$

Pada prinsipnya bank baru memutuskan memberikan kredit, apabila bank telah memperoleh keyakinan tentang nasabahnya. Keyakinan tersebut didasarkan atas hasil analisis yang mendalam tentang itikad baik nasabah dan kemampuan serta kesanggupan untuk membayar utangnya pada bank. Itikad baik nasabah diperoleh bank dari data-data yang disampaikan oleh nasabah dalam permohonan kreditnya. Untuk memperoleh keyakinan tersebut maka dilakukan penilaian terhadap watak, kemampuan, modal, agunan dan prospek usaha debitur. Dalam dunia perbankan kelima factor yang dinilai

1 Rachmadi Usman, Aspek-aspek Hukum Perbankan di Indonesia (Jakarta: Gramedia Pustaka Utama, 2003). tersebut dikenal dengan sebutan the five of credit analysis. ${ }^{2}$

Dalam pemberian kredit oleh bank kepada nasabah saat ini masih sangat menekankan pada arti pentingnya jaminan kredit. Jaminan kredit dibutuhkan oleh bank untuk mendapatkan kepastian atas pelunasan hutang dari nasabah setelah jangka waktu yang telah diperjanjikan dalam perjanjian kredit dengan membuat perjanjian jaminan. Jaminan kredit adalah pemberian keyakinan kepada pihak kreditor atas pembayaran utang yang telah diberikannya kepada debitor, yang terbit dari suatu perjanjian yang bersifat tambahan (assessoir) terhadap perjanjian pokoknya. ${ }^{3}$ Pada praktik perbankan, untuk memberi pengamanan yang lebih terhadap dana yang disalurkan oleh kreditor kepada debitor, dibutuhkan jaminan khusus yang sering digunakan yaitu jaminan kebendaan berupa tanah. Penggunaan tanah sebagai jaminan kredit didasarkan pada pertimbangan bahwa tanah mempunyai nilai ekonomis yang relatif tinggi.

2 Supramono, G, Perbankan dan Masalah Kredit (Jakarta: Rineka Cipta, 2009).

3 Munir Fuady, Hukum Jaminan Utang, (Jakarta: Erlangga, 2013). 
Asuan, Perlindungan Hukum Lelang Eksekusi Hak Tanggungan, Halaman 272-289

Jaminan kebendaan yang disebutkan dalam memori dibebankan terhadap tanah tersebut penjelasannya, yaitu sebagai berikut: disebut dengan hak tanggungan atas tanah. Ketentuan-ketentuan mengenai pembebanan hak tanggungan atas jaminan pinjaman telah diatur dalam Undang-undang Nomor 4 Tahun 1996 tentang Hak Tanggungan Atas Tanah Beserta Benda-Benda yang Berkaitan dengan Tanah (selanjutnya disebut UUHT) yang mengatur tentang jaminan antara bank dengan debitor dalam transaksi pinjam-meminjam serta memuat peraturan- peraturan tentang tata cara yang dapat ditempuh apabila debitor tidak melaksanakan kewajabannya (wanprestasi). ${ }^{4}$ Pemanfaatan lembaga eksekusi Hak Tanggungan merupakan cara untuk mempercepat pelunasan piutang agar dana yang telah dikeluarkan oleh bank dapat digunakan kembali untuk melakukan kegiatan pembiayaan terhadap debitornya. Adapun yang merupakan ciri-ciri hak tanggungan menurut UndangUndang Hak Tanggungan Nomor 4 Tahun 1996 adalah seperti yang

${ }^{4}$ Roni Mantiri, "Eksekusi Hak Tanggungan pada Kredit Macet," 2021, https://www.djkn.kemenkeu.go.id/2013/berita media/eksekusi-hak-tanggungan-kredit-macet.

1. Memberikan hak preferensi kepada pemegangnya

2. Mengikuti objek yang dijamin, dalam tangan siapapun objek itu berada.

3. Memenuhi asas spesialitas dan publisitas sehingga mengikat pihak ketiga dan memberikan kepastian hukum.

4. Mudah dan pasti pelaksanaan eksekusinya. ${ }^{5}$

Sebagai tanda bukti adanya hak tanggungan, maka dibutuhkan sertifikat hak tanggungan yang diterbitkan oleh Kantor Pertanahan serta memuat irah- irah "Demi Keadilan Berdasarkan Ketuhanan Yang Maha Esa". 6 Sertifikat Hak Tanggungan tersebut memiliki kekuatan eksekutorial yang sama dengan putusan pengadilan yang telah mempunyai kekuatan hukum tetap dan berlaku sebagai pengganti grosse acte Hyphoteek sepanjang mengenai hak atas tanah. Sertifikat tersebut akan memberikan kemudahan dan kepastian hukum bagi kreditor apabila

\footnotetext{
5 Munir Fuady, Hukum Perkreditan Kontemporer (Bandung: Citra Aditya Bakti, 2002).

${ }^{6}$ Undang-Undang Nomor 4 Tahun 1996

Tentang Hak Tanggungan
} 
Asuan, Perlindungan Hukum Lelang Eksekusi Hak Tanggungan, Halaman 272-289

suatu saat debitor melakukan wanprestasi.

Pada prakteknya, apabila debitor melakukan cidera janji (wanprestasi), maka kreditor atau pemegang hak tangungan mengirimkan surat peringatan sebanyak tiga kali kepada debitor supaya melunasi hutangnya. Apabila setelah dilakukan tiga kali peringatan secara patut debitor tetap tidak melunasi hutangnya, maka debitor dapat dikatakan wanprestasi sehingga pemegang hak tanggungan dalam hal ini dapat melakukan eksekusi terhadap hak tanggungan yang dibebankan atas jaminan hutang. Eksekusi yang dimaksud yaitu lelang terhadap objek jaminan yang dibebankan hak tanggungan.

Pasal 6 UUHT menyatakan bahwa apabila debitor cidera janji, pemegang hak tanggungan pertama mempunyai hak untuk menjual objek hak tanggungan atas kekuasaan sendiri melalui pelelangan umum serta mengambil pelunasan piutangnya dari hasil lelang tersebut. Tata cara eksekusi yang diatur dalam Pasal 6 UUHT tersebut biasa disebut dengan Parate Executie. Berdasarkan pasal tersebut, hak dari pemegang hak tanggungan untuk melaksanakan haknya adalah hak yang semata-mata diberikan oleh undang-undang. Walau demikian, tidak berarti hak tersebut demi hukum ada melainkan harus diperjanjikan terlebih dahulu oleh para pihak dalam Akta Pembebanan Hak Tanggungan atas hak atas tanah. ${ }^{7}$

Berdasarkan UUHT terdapat tiga macam eksekusi hak tanggungan yaitu Title Executorial, Parate Executie, dan Eksekusi Dibawah Tangan. Membedakan ketiga macam eksekusi hak tanggungan tersebut yaitu terdapat pada prosedur pelaksanaannya. Eksekusi hak tanggungan dengan Title Executorial yaitu penjualan barang eksekusi hak tanggungan dilakukan berdasarkan irah-irah "Demi Keadilan Berdasarkan Ketuhanan Yang Maha Esa" yang dilakukan melalui tata cara sesuai dengan Hukum Acara Perdata. Sedangkan untuk Eksekusi Dibawah Tangan harus memenuhi unsur yang tercantum dalam Pasal 20 UUHT yaitu adanya kesepakatan antara pemberi hak tanggungan dan pemegang hak tanggungan. ${ }^{8}$

\footnotetext{
${ }^{7}$ Kartini Mulydi and Gunawan Widjaja, Seri Hukum Harta Kekayaan: Hak Tanggungan (Jakarta: Kencana Prenada Media, 2005).

8 Hasanuddin Rahman, Aspek-Aspek Pembrian Kredit Perbankan Di Indonesia (Bandung: Citra Aditya Bakti, 1995).
} 
Asuan, Perlindungan Hukum Lelang Eksekusi Hak Tanggungan, Halaman 272-289

Pada pelaksanaannya, kreditor atau pemegang hak tanggungan pertama biasanya melakukan eksekusi hak tanggungan dengan cara parate executie. Parate executie tersebut biasanya dilakukan oleh pemegang hak tanggungan pertama apabila debitor waprestasi melalui Kantor Pelayanan Kekayaan Negara dan Lelang (selanjutnya disebut KPKNL). Parate executie sering dilakukan oleh kreditor pemegang hak tanggungan karena dianggap lebih mudah, biaya lebih murah, pelaksanaannya lebih singkat, serta kreditor tidak harus meminta fiat dari ketua Pengadilan untuk mengeksekusi hak tanggungan tersebut.

Pengaturan mengenai tatacara melakukan lelang itu sendiri termuat di dalam Peraturan Menteri Keuangan Nomor 27/PMK.06/2016 Tentang Petunjuk Pelaksanaan Lelang (Selanjutnya disebut PMK Petunjuk Pelaksanaan Lelang). Dalam Pasal 5 peraturan ini, menyatakan terdapat tiga jenis lelang yaitu lelang eksekusi, lelang noneksekusi wajib, dan lelang noneksekusi sukarela. Parate executie merupakan jenis eksekusi yang termasuk dalam lelang noneksekusi sukarela. Ketentuan Pasal 1 Angka 6
PMK Petunjuk Pelaksanaan Lelang telah dijelaskan mengenai lelang noneksekusi sukarela yaitu lelang atas barang milik swasta, perorangan atau badan hukum/badan usaha yang dilelang secara sukarela. Meskipun segala ketentuan dan tatacara pelaksanaan lelang sudah diatur dalam Peraturan Menteri Keuangan Nomor 27/PMK.06/2016 Tentang etunjuk Pelaksanaan Lelang, namun pada pelaksanaannya masih banyak permasalahan atau konflik yang terjadi. Misalnya konflik yang timbul akibat pihak ketiga yang keberatan kemudian mengajukan gugatan melalui Pengadilan. Konflik tersebut tentunya akan menyusahkan pihak bank selaku kreditor dan merugikan pemenang lelang karena tidak dapat langsung menguasai objek lelang. Hal tersebut menimbulkan tidak adanya kepastian hukum bagi pemenang lelang karena tidak dapat langsung mendapatkan hak nya secara yuridis dan materil.

Menurut uraian diatas yang suatu permasalahan yaitu bagaimanan perlindungan hukum terhadap lelang eksekusi hak tanggungan menurut Undang-undang hak tanggungan Nomor 4 tahun 1996 dan hambatan 
Asuan, Perlindungan Hukum Lelang Eksekusi Hak Tanggungan, Halaman 272-289

dalam pelaksanaan eksekusi hak tanggungan pada bank. Penelitian ini menggunakan metode yuridis normatif dengan bahan hokum berupa peraturan perundang-undangan mengenai lelang dan eksekusi hak tanggungan.

\section{PEMBAHASAN}

A. Perlindungan

Hukum

Terhadap Lelang Eksekusi Hak Tanggungan Dalam Perjanjian Kredit Bank

Bank merupakan salah satu lembaga pembiayaan yang dapat meningkatkan perekonomian melalui penyaluran dana berupa kredit kepada masyarakat untuk pengembangan usaha. Seperti yang telah dipaparkan sebelumnya, bank dalam memberikan kredit haruslah menerapkan prinsip kehati-hatian karena setiap kredit yang diberikan oleh bank mengandung resiko. Oleh karena itu, dibutuhkanya suatu jaminan untuk menjamin pelunasan utang debitor dalam perjanjian kredit.

Perjanjian kredit harus diperhatikan oleh bank selaku kreditor maupun oleh nasabah selaku debitor karena perjanjian kredit merupakan perjanjian pokok dan mempunyai fungsi yang sangat penting. Dengan adanya perjanjian kredit sebagai perjanjian pokok maka dapat diikuti dengan perjanjian tambahan seperti perjanjian jaminan. Perjanjian jaminan adalah perjanjian accesoir (tambahan) yang dikaitkan dengan perjanjian pokok untuk menjamin hak-hak kreditor apabila debitor tidak dapat memenuhi prestasi. Salah satu lembaga jaminan yang sering digunakan dalam praktek pemberian kredit yaitu lembaga jaminan hak tanggungan. ${ }^{9}$

Penjelasan Umum angka 7 UUHT mengatur mengenai prosedur pembebanan Hak Tanggungan yang menyatakan bahwa:

1. Tahap pemberian hak tanggungan dengan dibuatnya hak tanggungan oleh Pejabat Pembuat Akta Tanah (Selanjutnya disingkat PPAT), yang sebelumnya didahului oleh perjanjian utang-piutang yang dijamin.

2. Tahap pendaftaran oleh Kantor Pertanahan, yang merupakan saat lahirnya hak tanggungan.

Berdasarkan ketentuan tersebut, dapat diketahui bahwa pembebanan hak tanggungan atas hak milik dilakukan sesuai prosedur yang diatur dalam peraturan perundang-undangan

9 Rachmadi Usman, Hukum Jaminan Keperdataan (Jakarta: Sinar Grafika, 2016). 
Asuan, Perlindungan Hukum Lelang Eksekusi Hak Tanggungan, Halaman 272-289

yang berlaku. Hal tersebut

tersebut telah memenuhi syarat

dikarenakan pemberian hak

spesialitas hak tanggungan. ${ }^{10}$

tanggungan oleh debitor telah

Pembebanan Hak Tanggungan

dilakukan dihadapan notaris sehingga

terbit Akta Pembebanan Hak

Tanggungan (APHT) dan telah

didaftarkan di Kantor Pertanahan

sehingga lahir Surat Hak Tanggungan

(SHT) sebagai bukti adanya hak tanggungan dan mempunyai kekuatan

eksekutorial yang sama dengan

putusan pengadilan karena memuat

irah-irah "Demi Keadilan Berdasarkan

Ketuhanan Yang Maha Esa.”

Pengikatan hak tanggungan

tersebut telah didahului dengan

perjanjian pengikatan jaminan yang

merupakan perjanjian accesoir dari

perjanjian pemberian fasilitas

perbankan seperti yang telah

disebutkan sebelumnya sebagai

perjanjian pokok. Dalam APHT

telah dicantumkan nama dan identitas

pemegang dan pemberi hak

tanggungan, domisili para pihak,

penunjukan secara jelas utang yang

dijaminkan pelunasannya dengan Hak

Tanggungan, nilai tanggungan serta

uraian yang elas terkait objek hak

tanggungan. Dengan telah

dicantumkannya hal-hal tersebut,

maka pembebanan hak tanggungan

tersebut dimaksudkan untuk menjamin hak- hak pihak bank selaku kreditor dalam hal pelunasan utang apabila debitor tidak mampu melunasi utangnya dalam jangka waktu yang telah ditentukan. Pembebanan hak tanggungan oleh debitor menimbulkan perlindungan terhadap kreditor serta mendapatkan kedudukan yang didahulukan dalam hal pelunasan utang terhadap objek yang dijaminkan. Dengan adanya jaminan hak tanggungan maka dapat memperkecil resiko yang dialami oleh bank akibat perjanjian pemberian kredit. ${ }^{11}$

Pemberian surat peringatan tersebut menunjukkan bahwa pihak bank (kreditur) beritikad baik untuk memberikan terhadap debitor untuk melunasi utangnya. Setelah diberikan surat peringatan yang ketiga terhadap debitor untuk memenuhi kewajibannya tetap tidak mendapatkan tanggapan, maka bank menetapkan

\footnotetext{
10 Sutedi Adrian, Hukum Hak Tanggungan (Jakarta: Sinar Grafika, 2010).

11 Sianturi Purnama Tioria, Perlindungan Hukum Terhadap Pembeli Barang Jaminan Tidak Bergerak Melalui Lelang (Bandung: Penerbit CV. Bandar Maju, 2013).
} 
Asuan, Perlindungan Hukum Lelang Eksekusi Hak Tanggungan, Halaman 272-289

kredit terhadap debitor merupakan kredit macet karena telah memenuhi kolektibilitas sebagai kredit macet. Penetapan kualitas kredit didasarkan pada ketentuan Peraturan Bank Indonesia nomor 14/15/PBI/2012 tentang Penilaian Kualitas Aset Bank Umum dan Peraturan Bank Indonesia nomor 7/2/PBI/2005 tentang Penilaian Kualitas Aktiva Bank Umum. Dengan ditetapkannya kredit macet tersebut, debitor telah melakukan wanprestasi. $^{12}$

Pihak bank melakukan parate executie (eksekusi secara langsung) melalui Kantor Pelayanan Kekayaan Negara dan Lelang (KPKNL). Eksekusi secara langsung yang dilakukan didasarkan pada Pasal 20 ayat (1) huruf a UUHT j.o. Pasal 6 UUHT dan Pasal 11 ayat (2) huruf e UUHT.Menurut Pasal 20 ayat (1) huruf a j.o. Pasal 6 UUHT apabila debitor melakukan wanprestasi maka kreditor pemegang hak tanggungan pertama mempunyai hak untuk menjual objek hak tanggungan atas kekuasaan sendiri melalui pelelangan umum dan mengambil pelunasan piutangnya melalui hasil penjualan objek hak tanggungan tersebut.

\footnotetext{
${ }^{12}$ Sianturi
}

Sedangkan Pasal 11 ayat (2) huruf e mensyaratkan adanya janji bahwa pemegang hak tanggungan pertama mempunyai hak untuk menjual atas kekuasaan sendiri objek hak tanggungan apabila debitor wanprestasi. ${ }^{13}$ Jika debitor tidak memenuhi kewajiban untuk melunasi utangnya, berdasarkan perjanjian utang-piutang, pihak bank selaku pemegang hak tanggungan dengan APHT tersebut diberikan kuasa untuk:

1. Menjual dihadapan umum secara lelang objek hak tanggungan baik seluruhnya maupun sebagian.

2. Mengatur dan menetapkan waktu, tempat, cara dan syaratsyarat penjualan.

3. Menerima uang penjualan, menandatangani serta menyerahkan kwitansi.

4. Menyerahkan apa yang dijual tersebut kepada pembeli yang bersangkutan.

5. Mengambil dari uang hasil penjualan tersebut seluruhnya atau sebagian untuk melunasi utang Debitor.

6. Melakukan hal-hal lain yang menurut Undang-undang dan

\footnotetext{
${ }^{13}$ Undang-Undang Nomor 4 Tahun 1996 Tentang Hak Tanggungan
} 
Asuan, Perlindungan Hukum Lelang Eksekusi Hak Tanggungan, Halaman 272-289

peraturan hukum yang berlaku diharuskan atau menurut pendapat pihak bank selaku kreditor perlu melaksanakan kuasa tersebut.

Berdasarkan pemaparan tersebut tindakan yang dilakukan bank tidak terdapat permasalahan. Dengan demikian dapat dikatakan bahwa tindakan yang dilakukan oleh bank telah dilakukan berdasarkan ketentuan dalam UUHT serta diperkuat dengan ketentuan dalam APHT. ${ }^{14}$

Selanjutnya pihak bank mengajukan permohonan lelang melalui KPKNL. Sebelumnya perlu diketahui peraturan mengenai lelang di Indonesia diatur di Vendu Reglement termuat dalam Ordonantie tanggal 28 Februari 1908 Staatsblad 1908 Nomor 189 telah beberapakal diubah terakhir dengan Staatsblad 1941 Nomor 3, yang mulai berlaku sejak tanggal 1 April 1908, hingga sekarang masih menjadi dasar hukum penyelenggaraan pelaksanaan pelelangan atau penjualan barang jaminan di muka umum di Indonesia.

14 Poesoko Herowati, Dinamika Hukum Parate Executie Obyek Hak Tanggungan (Yogyakarta: Aswaja Persindo, 2013).
Sedangkan untuk tatacara pelaksanaan lelang itu sendiri diatur dalam Peraturan Menteri Keuangan (selanjutnya disingkat PMK) Nomor 27/PMK.06/2016 Tentang Petunjuk Pelaksanaan Lelang. ${ }^{15}$

Setelah dilengkapinya dokumen oleh bank tersebut, maka KPKNL menerima permohonan lelang yang diajukan bank tersebut. Hal tersebut sesuai dengan ketentuan yang diatur dalam Pasal 13 PMK Nomor 27/PMK.06/2016 Tentang Petunjuk Pelaksanaan Lelang yang menyatakan bahwa Kepala KPKNL atau Pejabat Lelang Kelas II tidak boleh menolak permohonan lelang yang diajukan sepanjang dokumen persyaratan lelang telah lengkap dan memenuhi legalitas formal subjek dan objek lelang. Oleh karena itu, setelah pemeriksaan dokumen dianggap lengkap maka KPKNL menerima permohonan lelang yang diajukan oleh Bank. Setelah diterima, KPKNL menetapkan waktu pelaksanaan lelang. ${ }^{16}$

Dalam hal ini, pemenang lelang telah mengikuti proses lelang sesuai prosedur dan memenuhi persyaratan

\footnotetext{
${ }^{15}$ Rachmadi Usman, Hukum Lelang (Jakarta: Sinar Grafika, 2016).

${ }^{16}$ Rachmadi
} 
Asuan, Perlindungan Hukum Lelang Eksekusi Hak Tanggungan, Halaman 272-289

yang ditentukan oleh KPKNL selanjutnya pembeli lelang diharuskan membayar Bea Perolehan Hak atas Tanah dan Bangunan (BPHTB) sebelum memperoleh kwitansi dan risalah lelang. ${ }^{17}$

Pemberian risalah lelang tersebut merupakan implementasi dari Pasal 42 Vendureglement dan Pasal 92 ayat (1) PMK No. 27/PMK.06/2016 tentang Petunjuk Pelaksanaan Lelang yang pada intinya menerangkan hakhak pembeli lelang yaitu mendapatkan salinan berita acara yang diotentikkan mengenai penjualan dengan disertai bea materai. Selain itu dalam Pasal 92 ayat (2) huruf a yang mengatur mengenai kegunaan risalah lelang bagi pembeli lelang yaitu sebagai akta jual beli untuk kepentingan balik nama di Kantor Pertanahan. Dengan demikian, dapat disimpulkan bahwa dalam pelaksanaan lelang tersebut telah dilakukan berdasarkan

Vendureglement termuat dalam Ordonantie tanggal 28 Februari 1908 Staatsblad 1908 Nomor 189 telah beberapakali diubah terakhir dengan Staatsblad 1941 Nomor 3, yang mulai berlaku sejak tanggal 1

17 Naja H. R. Daeng, Hukum Kredit dan Bank Garansi (Bandung: Citra AdityaBakti, 2005).
April 1908, hingga sekarang. Selain itu pelaksanaan lelang tersebut juga telah sesuai dengan ketentuan yang diatur dalam PMK Nomor: 27/PMK.06/2016 Tentang Petunjuk Pelaksanaan Lelang. ${ }^{18}$

Perlindungan hukum hak pemenang lelang eksekusi hak tanggungan, memang perlindungan terhadap pemenang lelang eksekusi hak tanggungan belum secara jelas diatur dalam peraturan perundangundangan. Padahal dalam kasus tersebut pemenang lelang merupakan pembeli yang beritikad baik. Itikad baik dari pembeli lelang tersebut dapat dibuktikan dengan kelengkapan syarat-syarat yang dibutuhkan untuk mengikuti lelang serta melaksanakan pelelangan sesuai prosedur dan tidak bertentangan dengan peraturan perundang-undangan. ${ }^{19}$

Lelang dalam hal ini dapat dipersamakan dengan jual-beli sebagaimana tercantum dalam Pasal 1457 KUHPerdata. Apabila dihubungkan dengan pasal 584 KUHPerdata j.o. Pasal 531 KUHPerdata maka, seorang pembeli dapat dikatakan beritikad baik apabila telah melaksanakan sesuai dengan

\footnotetext{
18 Naja

${ }^{19}$ Rachmadi Usman, Hukum Lelang
} 
Asuan, Perlindungan Hukum Lelang Eksekusi Hak Tanggungan, Halaman 272-289

prosedur, menuhi persyaratan sebagai pembeli, serta sesuai dengan asas-asas dalam penjualan melalui lelang. Pada kasus ini, pembeli lelang telah memenuhi persyaratan dan sesuai prosedur sehingga dapat dikatakan sebagai pembeli beritikad baik. Sudah sepantasnya lah pembeli beritikad baik dilindungi hak-hak nya.

Perlindungan terhadap pembeli lelang eksekusi hak tanggungan sebenarnya secara tidak langsung telah diatur secara preventif. Perlindungan secara preventif terhadap pemenang lelang hak tanggungan yaitu suatu bentuk perlindungan yang diberikan sebelum terjadinya sengketa terkait objek lelang, sehingga bersifat pencegahan. ${ }^{20}$

Perlindungan secara preventif dalam vendu reglement yaitu terdapat dalam Pasal 42 vendu reglement yang menentukan bahwa pemenang lelang dapat menerima kutipan berita acara yang diotentikan atau yang disebut dengan kutipan risalah lelang. Pemberian risalah lelang disini dapat

${ }^{20}$ Hadjon Philipus M., Perlindungan Hukum Bagi Rakyat Indonesia: Sebuah Studi Tentang Prinsip-Prinsipnya, Penanganannya Oleh Peradilan Dalam Lingkup Peradilan Umum dan Pembentukan Peradilan Administrasi Negara (Surabaya: Bina Ilmu, 1987). dipersamakan sebagai akta perjanjian jual beli. Kedudukan kutipan risalah lelang sejajar dengan akta perjanjian jual beli yang dibuat oleh Pejabat Pembuat Akta Tanah (PPAT) sehingga dapat digunakan untuk kepentingan peralihan hak terhadap objek lelang hak tanggungan di Kantor Pertanahan.Ketentuan Umum Pasal 1 $\begin{array}{llll}\text { angka } & 35 & \text { PMK } & \text { Nomor }\end{array}$ 27/PMK.06/2016 tentang Petunjuk Pelaksanaan Lelang menyatakan bahwa risalah lelang adalah berita acara pelaksanaan lelang yang merupakan akta otentik yang mempunyai kekuatan pembuktian sempurna. Berdasarkan pengertian risalah lelang dalam pasal tersebut maka dapat disimpulkan bahwa pembeli lelang dapat membuktikan dengan risalah lelang bahwa telah terjadi perjanjian jual-beli melalui lelang eksekusi hak tanggungan.

Risalah lelang tersebut harus memuat apa, mengapa, di mana, bila, bagaimana, serta siapa-siapa yang terlibat dalam pelaksanaan lelang. Apa yang dilelangkan menjelaskan mengenai objek atas barang yeng dilelang. Mengapa dilakukan pelelangan menjelaskan mengenai 
Asuan, Perlindungan Hukum Lelang Eksekusi Hak Tanggungan, Halaman 272-289

latar belakang hingga dilakukannya

lelang tersebut. Di mana dilelangkan menjelaskan mengenai tempat di mana lelang dilakukan dan kapan lelang tersebut dilaksanakan. Bagaimana pelaksanaan lelang menjelaskan proses terjadinya penawaran hingga ditunjuknya pemenang lelang. Siapa-siapa yang terlibat dalam lelang menjelaskan terkait siapa pemohon atau penjual lelang siapa penawar dalam lelang, dan siapa pembeli lelang. ${ }^{21}$

Akan tetapi, risalah lelang tidak dapat menjamin perlindungan hukum bagi pembeli lelang eksekusi hak tanggungan. Hal tersebut dikarenakan dalam klausula risalah lelang tercantum pernyataan:

1. Pejabat Lelang/KPKNL tidak menanggung kebenaran keterangan yang diberikan secara lisan yang diberikan pada waktu penjualan tentang keadaan nsesungguhnya dan keadaan hukum atas barang yang dilelang, dan menjadi resiko pembeli.

2. Penawar/pembeli dianggap bersungguh-sungguh telah mengetahui apa yang telah

\footnotetext{
${ }^{21}$ Rachmadi Usman, Hukum Lelang
}

ditawar atau dibeli oleh merka apabila terdapat kekuragan dan kerusakan baik yang terlihat maupun tidak terlihat atau terdapat cacat lainnya terhadap bidang tanah atau bangunan barang yang dibelinya itu, maka mereka tidak berhak menolak atau menarik diri kembali setelah pembeliannya disahkan dan melepaskan semua hak untuk meminta ganti kerugian berupa apapun juga.

Perlindungan bagi pemenang lelang hak tanggungan sebenarnya telah dilakukan secara preventif oleh KPKNL karena sebelum dilakukannya pelelangan, KPKNL memberitahukan kepada peserta lelang terkait dengan dokumen-dokumen, keadaan dan kondisi objek yang akan dilelang dengan sebenar-benarnya dan apa adanya, serta konsekuensi dan resiko yang dapat timbul dari objek lelang. Peserta lelang dianggap mengetahui dengan sesungguhnya serta menerima konsekuensi akibat pelelangan objek hak tanggungan dengan dilakukannya tindakan preventif oleh KPKNL tersebut. Selain itu, Pejabat lelang wajib 
Asuan, Perlindungan Hukum Lelang Eksekusi Hak Tanggungan, Halaman 272-289

meminta keterangan kepada Kantor Pertanahan terkait dengan bidang tanah yang akan dilelang. Hal tersebut dilakukan selambat-lambatnya 7 hari sebelum pelaksanaan lelang untuk memastikan kejelasan objek lelang. Kewajiban Pejabat Lelang selaku perantara terhadap penjual maupun pembeli bertindak hati-hati dalam melaksanakan tugasnya, serta memberikan informasi yang penting yang diketahuinya. Pejabat lelang harus berhati-hati dalam melaksanakan lelang baik untuk kepentingan penjual maupun kepentingan pembeli serta membrikan informasi yang sejelas-jelasnya termasuk tentang barang atau objek kepada pembeli. ${ }^{22}$

Dikarenakan pelaksanaan lelang disini dapat dipersamakan dengan perjanjian jual beli sebagaimana diatur dalam KUH Perdata, maka perlindungan hukumnya juga terdapat dalam KUH Perdata. Berdasarkan KUH Perdata, pembeli beritikad baik haruslah dilindungi. Bentuk perlindungan terhadap pembeli beritikad baik tersebut termuat dalam Pasal 1491 KUHPerdata yang

\footnotetext{
${ }^{22}$ Sutedi Adrian, Hukum Hak Tanggungan
}

menyatakan bahwa penanggungan yang menjadi kewajiban penjual terhadap pembeli, adalah untuk menjamin dua hal yaitu pertama penguasaan benda yang dijual secara aman dan tentram, kedua terhadap adanya cacat-cacat barang yang tersembunyi atau yang sedemikian rupa hingga menerbitkan alasan untuk pembatalan pembeliannya.

Selain perlindungan dalam Pasal $1491 \quad$ KUHPerdata, perlindungan terhadap pembeli juga dapat dilakukan dengan mengajukan gugatan ganti rugi. Hal tersebut didasarkan pada Pasal 1267 KUHPerdata yang menyatakan bahwa pihak terhadap siapa perikatan tidak dipenuhi, dapat memilih apakah dia, jika hal itu masih dapat dilakukan, akan memaksa pihak yang lain untuk memenuhi persetujuan, ataukah dia akan menuntut pembatalan persetujuan, disertai penggantian biaya, kerugian dan bunga. Berdasarkan pasal tersebut maka jelas pembeli dilindungi untuk memperoleh hak nya. Perlindungan hukum terhadap pemenang lelang dapat ditemukan dalam Pasal 4 PMK Nomor 27/PMK.06/2016 tentang Petunjuk Pelaksanaan Lelang yang menyatakan 
Asuan, Perlindungan Hukum Lelang Eksekusi Hak Tanggungan, Halaman 272-289

bahwa lelang yang telah dilakukan sesuai dengan ketentuan yang berlaku tidak dapat dibatalkan. Berdasarkan pasal tersebut dapat terlihat bahwa kepastian hukum bagi pemenang lelang hak tanggungan terjamin. Selain itu perlindungan secara preventif juga dapat terlihat dalam Pasal 12 PMK Nomor 27/PMK.06/2016 tentang Petunjuk Pelaksanaan Lelang yang mengatur mengenai kewajiban bagi penjual lelang untuk melengkapi dokumen dan legalitas formal terkait objek yang akan dilelang. Selanjutnya Pejabat Lelang KPKNL melakukan analisis yuridis terhadap dokumen persyaratan lelang, legalitas formal serta keabsahan objek lelang. Hal tersebut memberikan kepastiaan hukum bagi pembeli lelang karena lelang dapat dilaksanakan sesuai prosedur yang diatur dalam peraturan perundangundangan. ${ }^{23}$

Terkait dengan penyerahan dokumen kepemilikan atas objek lelang bukan merupakan kewenangan KPKNL, tetapi merupakan tanggungjawab penjual lelang dalam hal ini pihak bank/kreditur. Hal tersebut diatur dalam Pasal 17 PMK

${ }^{23}$ Sutedi
Nomor: 27/PMK.06/2016 tentang Petunjuk Pelaksanaan Lelang yang menyatakan bahwa:

(1) Penjual bertanggung jawab terhadap: a. keabsahan kepemilikan barang; b. keabsahan dokumen persyaratan lelang; c. penyerahan barang bergerak dan/atau tidak bergerak dan d. penetapan nilai limit.

(2) Penjual bertanggung jawab terhadap gugatan perdata dan/atau tuntutan pidana yang timbul akibat tidak dipenuhinya peraturan perundang- undangan di bidang lelang oleh Penjual.

(3) Penjual bertanggung jawab atas tuntutan ganti rugi terhadap kerugian yang timbul, dalam hal tidak memenuhi tanggung jawab sebagaimana dimaksud pada ayat (1).

(4) Penjual harus menguasai fisik barang bergerak yang akan dilelang, kecuali barang tak berwujud, antara lain hak tagih, hak cipta, hak merek, dan/atau hak paten.

(5) Penjual dapat menggunakan balai lelang untuk memberikan jasa pralelang dan/atau jasa pasca lelang.

Selain dalam pasal tersebut, kewajiban penjual terhadap barang yang dijualnya juga termuat dalam KUH Perdata. Pasal 1474 KUHPerdata menyatakan bahwa penjual memiliki kewajiban untuk:

1. Memelihara dan merawat kebendaan yang akan diserahkan kepada pembeli hingga saat penyerahannya. 
Asuan, Perlindungan Hukum Lelang Eksekusi Hak Tanggungan, Halaman 272-289

2. Menyerahkan kebendaan yang dijual pada saat yang telah ditentukan, atau jika tidak telah ditentukan saatnya, atas permintaan pembeli.

Berdasarkan pasal-pasal tersebut dapat terlihat kepastian dan perlindungan hukum terhadap pemenang lelang. Hal tersebut dikarenakan hak-hak pemenang lelang terjamin oleh kewajiban serta tanggung jawab yang harus dilakukan oleh penjual lelang sesuai dengan pasal tersebut. Peraturan tersebut mencerminkan bahwa dalam pelaksanaan pra lelang maupun pasca lelang tidak hanya menekankan pada faktor kehati-hatian pembeli lelang saat pembelian barang, tetapi juga faktor kehati-hatian menjadi tanggung jawab penjual. Tanggung jawab tersebut diatur dengan tegas sehingga pada pemberian ganti rugi yang timbul karena ketidak absahan barang dan dokumen persyaratan barang tanggung jawab berada pada penjual.

Selain

dalam

vendureglement dan Peraturan

Mentri Keuangan, Perlindungan terhadap pemenang lelang secara represif termuat dalam HIR.
Perlindungan represif yaitu upaya untuk mendapatkan perlindungan hukum yang dilakukan melalui badan peradilan. Pasal 200 ayat (11) HIR mengatur mengenai eksekusi riil atau eksekusi pengosongan yang pada intinya menyatakan bahwa apabila pemenang lelang tidak dapat menguasai objek lelang yang telah dibelinya melalui pelelangan yang sah demi hukum, maka pemenang lelang dapat meminta bantuan kepada Pengadilan Negeri setempat untuk melakukan pengosongan terhadap objek lelang tersebut. ${ }^{24}$

\section{B. Hambatan Dalam Pelaksanaan}

\section{Eksekusi Hak Tanggungan}

Ada beberapa faktor lain yang menyebabkan terjadinya hambatan dalam eksekusi Hak Tanggungan baik melalui pelelangan umum maupun penjualan di bawah tangan atara lain:

\section{Debitur yang Berbelit-belit}

Hambatan ini disebabkan oleh pihak debitur dan/atau penjamin yang sulit untuk berkoordinasi dalam melakukan mediasi. Susahnya debitur dan/atau penjamin untuk diajak mediasi dengan pihak bank dalam

${ }^{24}$ Hadjon, Philipus, Perlindungan Hukum Bagi Rakyat Indonesia (Surabaya: Bina Ilmu, 1997). 
Asuan, Perlindungan Hukum Lelang Eksekusi Hak Tanggungan, Halaman 272-289

menyelsaikan permasalahan kredit

macet akan mengulur waktu dengan sia-sia. Ulah debitur yang berusaha untuk mengulur waktu akan menghambat proses pelaksanan eksekusi Hak Tanggungan dengan harapan agar objek Hak Tanggungan tidak segera dijual. Hal ini menandakan ada iktikad tidak baik dari pihak debitur dan/atau penjamin dalam pelaksanaan eksekusi Hak Tanggungan.

\section{Ketidakcocokan Harga}

Dalam hambatan ini disebabkan oleh pihak debitur yang tidak setuju terhadap harga lelang agunan. Pihak kreditur dalam menetapkan harga sudah sesuai dengan Nilai Pasar Wajar (NPW), tetapi disisi lain yaitu pihak debitur dan/penjamin merasa keberatan karena harga yang ditetapkan terlalu rendah. Debitur tidak rela jika jaminannya dijual dengan harga murah karena menurutnya harga jaminannya bisa melebihi harga limit yang ditentukan oleh pihak kreditur. Jadi harus dilakukan negoisasi lagi untuk menemukan kecocokan harga supaya tidak ada yang keberatan. ${ }^{25}$

${ }^{25}$ Salim H.S., Perkembangan Hukum Jaminan di Indonesia (Jakarta: Rajawali Pers, 2004).
Hambatan-hambatan

yang

timbul dari pelaksanaan eksekusi hak tanggungan tidak hanya disebabkan oleh pihak debitur dan/penjamin saja tetapi juga disebabkan oleh kedua belah pihak yaitu pihak debitur dan/atau penjamin dengan pihak kreditur yang lama bernegoisasi untuk menemukan kecocokan harga agar tidak ada yang keberatan. Hal ini tentu bertentangan dengan ketentuan Pasal 6 Undang-undang Hak Tanggungan yang yang memberikan hak untuk menjual objek hak tanggungan atas kekuasaan sendiri melalui pelelangan umum serta mengambil pelunasannya dari hasil penjualan tersebut dan juga bertentangan dengan asas hak tanggungan yaitu pelaksanaan eksekusi hak tanggungan mudah dan pasti.

\section{KESIMPULAN DAN \\ REKOMENDASI}

Berdasarkan pembahasan maka dapat disimpulkan bahwa perlindungan lelang hak tanggungan sebenarnya telah dilakukan secara preventif oleh KPKNL karena sebelum dilakukannya pelelangan, KPKNL memberitahukan 
Asuan, Perlindungan Hukum Lelang Eksekusi Hak Tanggungan, Halaman 272-289

kepada peserta lelang terkait dengan dokumen-dokumen, keadaan dan kondisi objek yang akan dilelang dengan sebenar-benarnya dan apa adanya, serta konsekuensi dan resiko yang dapat timbul dari objek lelang. Terkait perlindungan secara represif yaitu upaya untuk mendapatkan perlindungan hukum melalui badan peradilan.

Hambatan dalam pelaksanaan eksekusi hak tanggungan yaitu debitur yang berbelit-belit dalam melakukan negoisasi untuk menyelesaikan kredit macet, ketidakcocokan terhadap harga lelang yang dilakukan oleh pihak debitur dan yang terakhir adalah adanya upaya perlawanan hukum dari pihak debitur yang melakukan gugatan ke Pengadilan Negeri. Hal tersebut jelas bertentangan dengan ketentuan Pasal 6 dan Pasal 20 Undang-Undang Hak Tanggungan tentang pelaksanaan eksekusi hak tanggungan.

Diharapkan kepada pemerintah khususnya Kantor (Pelayanan Kekayaan Negara dan Lelang) KPKNL perlunya pengaturan khusus mengenai perlindungan hukum pemenang lelang hak tanggungan. Sebelum dilakukannya lelang pada kreditur dan debitur harus membuat kesepakatan lebih dahulu mengenai harga objek lelang, sehingga tidak merugikan pembeli lelang tersebut.

\section{DAFTAR PUSTAKA}

Hadjon Philipus M. Perlindungan Hukum Bagi Rakyat Indonesia: Sebuah Studi Tentang PrinsipPrinsipnya, Penanganannya Oleh Peradilan Dalam Lingkup Peradilan Umum dan Pembentukan Peradilan Administrasi Negara. Surabaya: Bina Ilmu, 1987.

Hadjon, Philipus. Perlindungan Hukum Bagi Rakyat Indonesia. Surabaya: Bina Ilmu, 1997.

Hasanuddin Rahman. Aspek-Aspek Pembrian Kredit Perbankan di Indonesia. Bandung: Citra Aditya Bakti, 1995.

Kartini Mulydi and Gunawan Widjaja. Seri Hukum Harta Kekayaan: Hak Tanggungan. Jakarta: Kencana Prenada Media, 2005.

Poesoko Herowati. Dinamika Hukum Parate Executie Obyek Hak Tanggungan. Yogyakarta: Aswaja Persindo, 2013.

Rachmadi Usman. Aspek-aspek Hukum Perbankan di Indonesia. Jakarta: Gramedia Pustaka Utama, 2003.

Rachmadi Usman. Hukum Lelang. Jakarta: Sinar Grafika, 2016.

Rachmadi Usman. Hukum Jaminan Keperdataan. Jakarta: Sinar Grafika, 2016.

Roni Mantiri, "Eksekusi Hak Tanggungan pada Kredit Macet," 2021, https://www.djkn.kemenkeu.go.i $\mathrm{d} / 2013 /$ beritamedia/eksekusihak-tanggungan-kredit-macet.

Salim H.S. Perkembangan Hukum Jaminan di Indonesia. Jakarta: 
Asuan, Perlindungan Hukum Lelang Eksekusi Hak Tanggungan, Halaman 272-289

Rajawali Pers, 2004.

Sianturi Purnama Tioria.

Perlindungan Hukum Terhadap

Pembeli Barang Jaminan Tidak

Bergerak Melalui Lelang.

Bandung: Penerbit CV. Bandar

Maju, 2013.

Sutedi Adrian. Hukum Hak

Tanggungan. Jakarta: Sinar

Grafika, 2010.

Supramono, G. Perbankan dan

Masalah Kredit. Jakarta: Rineka

Cipta, 2009.

Munir Fuady. Hukum Perkreditan

Kontemporer. Bandung: Citra Aditya Bakti, 2002.

Munir Fuady. Hukum Jaminan Utang. Jakarta: Erlangga, 2013.

Naja H. R. Daeng. Hukum Kredit dan Bank Garansi. Bandung: Citra AdityaBakti, 2005.

Undang-Undang Nomor 4 Tahun 1996

Tentang Hak Tanggungan 